ISSN 2548-7981 (Online)

\title{
Peningkatan Nilai Produktivitas Usaha Bumbu Pecel dengan Menggunakan Alat Sangrai Otomatis
}

\author{
Sinar Perbawani Abrina Anggraini ${ }^{1)}$, Kun Ausssieanita Mediaswanti ${ }^{2)}$ \\ ${ }^{1,2}$ Program Studi Teknik Kimia, ${ }^{1,2}$ Fakultas Teknik, \\ ${ }^{1,2}$ Universitas Tribhuwana Tunggadewi Malang \\ 1 e-mail : abrina@unitri.ac.id
}

\begin{abstract}
ABSTRAK
Kebanyakan para pedagang bumbu pecel mengeluhkan saat proses penggorengan yang membutuhkan waktu yang lama hingga benar-benar matang merata, sehingga menyita banyak waktu saat proses pembuatannya. Hal ini mempengaruhi kualitas maupun kuantitas hasil proses produksi. Dibutuhkan efektivitas waktu saat pembuatan bumbu pecel sehingga akan meningkatkan produktivitas usaha bumbu pecel. Salah satu mitra usaha yaitu bumbu pecel "Bu Firda" yang membutuhkan perbaikan kualitas maupun kuantitas produk untuk menambah pendapatan keluarga. Perbaikan kualitas dan kuantitas bumbu pecel dengan membuat alat sangrai kacang secara otomatis untuk memaksimalkan hasil produk. Pada Program Kemitraan Masyarakat ini akan memberikan kegiatan antara lain memberikan pelatihan, penyuluhan dan pendampingan analisis kelayakan usaha menggunakan metode Break Event Point, penyusunan laporan keuangan, teknik kendali mutu produk, mendesain kemasan supaya lebih menarik serta pelatihan operasional alat sangrai sekaligus cara perawatannya. Selain itu, mitra juga diberikan pelatihan pemasaran e-commerce melalui media internet agar penjualan semakin luas sehingga menambah penghasilan bagi keluarga. Hasil dari kegiatan ini antara lain penghasilan meningkat menjadi 58\%, kapasitas bertambah 50\%, efektivitas waktu meningkat hingga 56\%, luas pemasaran meningkat 50\% dan beban pekerjaan lebih ringan dan cepat.
\end{abstract}

Kata kunci : alat sangrai; bumbu pecel; produktivitas; analisis BEP

\begin{abstract}
Most pecel seasoners complain about the frying process which takes a long time until it is completely cooked evenly, so it takes up a lot of time during the manufacturing process. This affects the quality and quantity of the production process. It takes the effectiveness of time when making pecel spices so that it will increase the productivity of pecel spices. One of the business partners is the "Bu Firda" pecel seasoning which requires product quality and quantity improvements to increase family income. Improving the quality and quantity of pecel seasoning by automatically making peanut roaster to maximize product yield. The Community Partnership Program will provide activities including providing training, counseling and mentoring business feasibility analysis using the Break Event Point method, preparing financial reports, product quality control techniques, designing packaging to make it more attractive and training in roasting equipment as well as how to maintain it. In addition, partners are also given e-commerce marketing training through internet media so that sales will be broader so as to increase income for families. The results of this activity included income increased to 58\%, capacity increased by 50\%, time effectiveness increased by 56\%, marketing area increased by 50\% and work load was lighter and faster.
\end{abstract}

Keywords : roaster; pecel; productivity; BEP analysis 


\section{PENDAHULUAN}

Kebanyakan dari UMKM bumbu pecel merasa resah dengan banyaknya pesaing di luar yang semakin tajam, terutama pada jenis usaha yang sama banyak menghasilkan bumbu pecel yang beraekaragam merk. Keluhan dari usaha bumbu pecel "Bu Firda" yang dipimpin oleh Ibu Budi yaitu alat sangrai yang digunakan hanya menggunakan wajan biasa dengan kapasitas terbatas realtif sedikit $2 \mathrm{~kg}$ selain membutuhkan waktu yang lama selama 30 menit. Jadi Bu Budi hanya mampu menghasilkan kapasitas produksi $10 \mathrm{~kg} / \mathrm{minggu}$. Beliau tidak bisa memenuhi permintaan pada sebesar $10 \%$ dari permintaan pasar $15 \mathrm{~kg} /$ minggu sekitar hanya $10 \mathrm{~kg} /$ minggu sehingga kebutuhan bumbu pecel yang mendesak tidak bisa terpenuhi.

Pada bentuk kemasan bumbu pecel "Bu Firda" yang dipimpin oleh bu Budi juga kurang menarik karena hanya ditempatkan pada mika plastik berukuran kecil yang terkesan sederhana sekali. Kemasan yang menarik akan mengundang banyak pelanggan meskipun bersamaan dengan timbunan produk lainnya sehingga mata pelanggan hanya tertuju pada kemasan yang lebih menarik. (Uchyani $\mathrm{R}$, dkk, 2016). Selain itu juga kurang higienis karena hanya menggunakan isolasi biasa untuk merapatkan mika plastik sehingga kurang tahan lama. Pada kemasan yang kurang rapat dapat menimbulkan jamur yaitu Aspergillus flavus. Biasanya jamur tersebut akan tumbuh pada tempat yang lembab pada proses pemyimpana yang kurang rapat sehingga akan berkontaminasi dengan produk makanan di dalam kemasan (Agnis F.R ,dkk, 2015). Pada kemasan bu Budi hanya ditutup mika plastik berukuran kecil tanpa menggunakan aluminium foil unuk mengbungkus bumbu pecel. Aluminium foil memiliki peran sebagai bahan pelindung untuk mencegah udara masuk sehingga dapat mempertahankan daya tahan lama simpan produk karena lebih higienis dan aman untuk produk pangan (Indrajaya Y.C., 2015). Lama waktu proses kemas menggunakan mika plastik membutuhkan waktu yang lebih lama untuk $2 \mathrm{~kg}$ bumbu pecel yaitu 5,5 jam.

Pada proses pemasaran hanya menggunakan sistem standar yaitu secara tradisonal saja yang dititipkan ke tokotoko untuk dapat dijual. Beliau tidak menggunakan sistem e-market atau $e$ commerce karena belum mengerti cara penggunannya atau kurang mengerti tentang IT. Pada permasalahan tersebut diatas, maka solusinya adalah perlu adanya rancangan alat sangrai otomatis dan membaut design kemasan untuk bumbu pecel. Tujuan dari kegiatan ini adalah memperbaiki kualitas proses sangrai kacang tanah dan design kemasan pada produk bumbu pecel dengan harapan akan menambah penghasilan mitra sehingga dapat meningkatkan taraf hidup keluarga.

\section{METODE KEGIATAN}

Metode yang digunakan adalah melalui pelatihan, penyuluhan dan pendampingan yaitu antara lain pelatihan cara menghitung analisa kelayakan usaha dengan BEP dan analisis swot, pelatihan cara membuat pembukuan laporan keuangan sederhana, pelatihan teknik komunikasi pemasaran, pelatihan kendali mutu produk, pelatihan dan pendampingan cara pengoperasian alat sangrai kacang, 
pelatihan dan pemdampingan teknik pengoperasian alat pengemas kontinue dan mesin coding serta pelatihan teknik bentuk kemasan yang menarik.

\section{- Pendidikan Masyarakat}

Untuk kegiatan a) pelatihan cara menghitung kelayakan usaha vdan analisis swot; b) pelatihan kendali mutu produk; c) pelatihan cara penyusunan laporan keuangan secara sederhana; dan d) pelatihan teknik komunikasi pemasaran yang bertujuan meningkatkan pemahaman dari segi manajemennya, sehingga menyadarkan masyarakat akan pentingnya manajemen dalam menjalankan usaha bumbu pecel.

\section{○ Konsultasi}

Memberikan penyuluhan maupun pendampingan dalam membuat laporan keuangan dan menghitung analisa usaha denga cara break even point. Memberikan pula untuk melakukan analisisi swot sesuai dengan strategi pemasaran usaha bumbu pecel.

○ Difusi Ipteks

Dalam kegiatan ini menghasilkan produk berupa alat teknologi tepat guna yaitu alat sangrai otomatis dan beberapa bulu modul yaitu tentang cara menghitung kelayakan usaha dan analisis swot, car membuat laporan keuangan sederhana, dan teknik komunikasi pemasaran. Memberikan design bentuk kemasan yang lebih menarik sehingga dapat mendatangkan pelanggan lebih banyak.

- Pelatihan

Pelatihan yang diberikan selain pengetahuan juga memberikan cara operasional alat sangrai otomatis dengan sekaligus pendampingan selama penggunakan alat tersebut. Tim pengabdi juga memberikan cara perawatan alat beserta memberikan program keberlanjutannya supaya lebih dapat mandiri dalam menjalankan usahanya denghan baik yaitu memberikan minyak pelumas dan kontak person untuk perbaikan alat atau tempat service alat jika alat tersebut mengalamai kerusakan.

\section{- Simulasi Ipteks}

Pada kegiatan ini juga memberikan simulasi cara pemasaran dengan sistem e-market yaitu menggunakan sarana internet berupa sosial media untuk memasarkan produk bumbu pecel sehingga akan lebih luas jangkauan pemasarannya hingga bisa lebih dari beberapa kota. Pada pemasaran bu Budi ini dari semula 2 kota sekarang bisa menjangkau sekitar 3 kota sebagai pelanggannya. Banyak permintaan dari luar sehingga dapat meningkatkan pendapatan keluarga.

\section{- Substitusi Ipteks}

Pada proses pembuatan bumbu pecel ini dengan memberikan bantuan berupa alat sangrai otomatis. Alat tersebut merupakan dapat meningkatkan efisiensi proses sangrai kacang tanah lebih cepat dan efisien, selain itu hasil sangrai kacang akan lebih merata kematangannya jika dibandingkan menggunakan penggorengan biasa. Waktu proses yang digunakan jauh lebih cepat daripada sebelumnya yaitu sekitar 56\% lebih cepat dan beban dirasa lebih ringan. Sebelumnya jika 2 kg memerlukan waktu 30 menit, maka jika menggunakan alat sangrai otomatis 
hanya memerlukan waktu sekitar 13 menit saja untuk $2 \mathrm{~kg}$.

\section{KARYA UTAMA}

Karya utama dalam kegiatan ini adalah alat sangrai otomatis. Alat ini digunakan untuk menyangrai bahan makanan untuk camilan maupun untuk proses yang lain (kacang tanah, kedelai, kopi, dll), dengan proses rotary atau berputar, maka over roasted atau gosong tidak akan terjadi, dikarenakan bahan yang disangrai berputar sehingga matang merata, dilengkapi dengan automatic controll suhu, dimana suhu yang diinginkan bisa diatur dengan memutar tombol penentuan suhu. Pada mesin Gambar 2 tersebut diatas akan menghasilkan produk matang merata, berbahan stainless steel, hemat biaya (LPG dan listrik), termostat control suhu otomatis, bisa disetting sesuai dengan keinginan kita. Bisa menuangkan hasil (arah putar bisa dibalik).

Spesifikasi pada alat sangrai ini adalah berkapasitas $5 \mathrm{~kg}$, dimensi 90 × 50 x $91 \mathrm{~cm}$, bahan bakar yag digunakan LPG, listri hanya 135 watt, $220 \mathrm{~V}$, bahan full stainless steel, memiliki pengatur suhu secara otomatis sehingga akan terkontrol tingkat kematangannya dan akan lebih merata hasilnya.

Selain itu design bentuk kemasan untuk produk bumbu pecel. Didesgn yang lebih menarik untuk para pelanggan sehingga akan menambah minat pelanggan untuk membeli produk bumbu pecel. Bentuk kemasan merupakan salah satu daya tarik pelanggan untuk membeli sehingga akan memenuhi beberapa pesanan tambahan dengan dibungkus terlebih dahulu dengan aluminim foil sehingga akan menambah daya lama simpan produk jadi lebih awet dalam penyinpanan yang lebih lama sekitar 5 bulan.
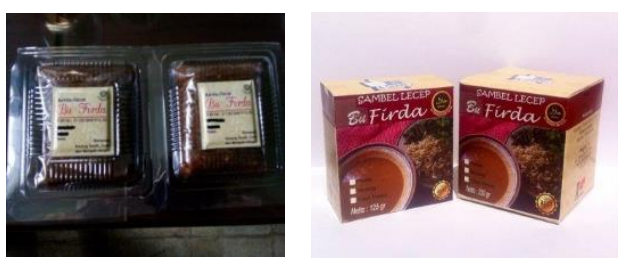

Gambar 1. Perubahan bentuk kemasan
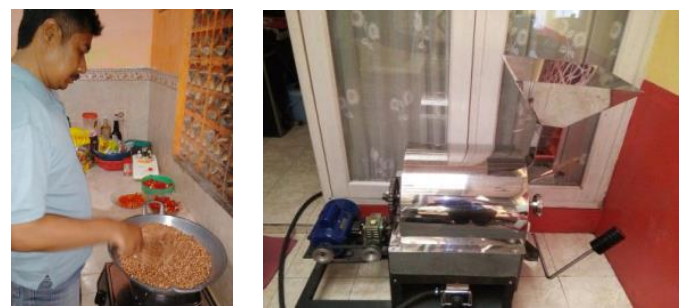

Gambar 2. Perubahan alat sangrai

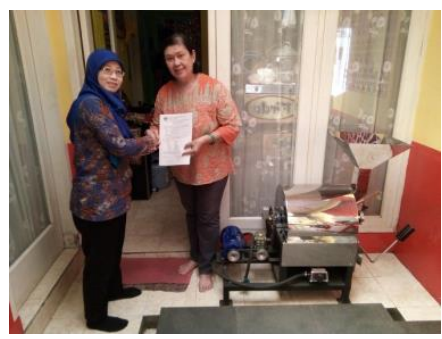

Gambar 3. Penyerahan alat sangrai
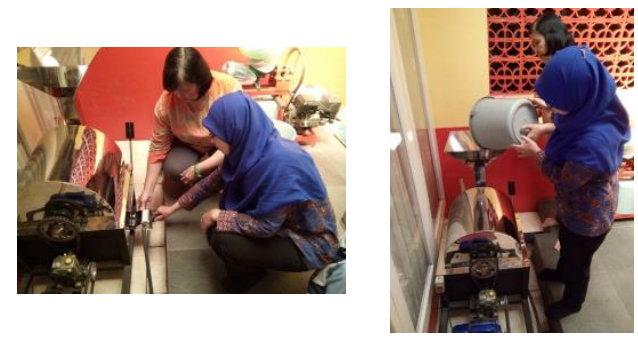

Gambar 4. Pelatihan dan pendampingan cara operasional alat sangrai beserta perawatannya

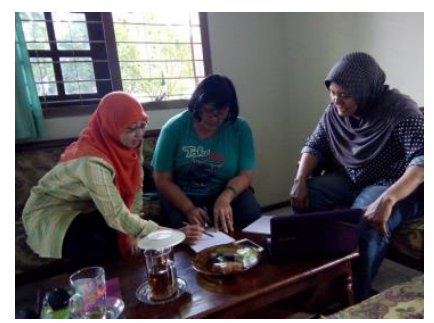

Gambar 5. Pelatihan cara penyusunan laporan keuangan sederhana dan cara menghitung kelayakan usaha 
Tabel 1. Hasil Program Kemitraan Masyarakat

\begin{tabular}{cccc}
\hline \multirow{2}{*}{ No } & Komponen & $\begin{array}{c}\text { Bebelum } \\
\text { PKM }\end{array}$ & $\begin{array}{c}\text { Sesudah } \\
\text { PKM }\end{array}$ \\
\cline { 3 - 4 } $\mathbf{1}$ & $\begin{array}{c}\text { Beban } \\
\text { Pekerjaan }\end{array}$ & Lebih berat & Lebih ringan \\
\hline $\mathbf{2}$ & $\begin{array}{c}\text { Lama Proses } \\
\text { (Efektivitas } \\
\text { Proses) }\end{array}$ & $\begin{array}{c}2 \mathrm{~kg}=30 \\
\text { menit }\end{array}$ & $\begin{array}{c}2 \mathrm{~kg}=13 \\
\text { menit } \\
(56 \%)\end{array}$ \\
\hline $\mathbf{3}$ & $\begin{array}{c}\text { Kapasitas } \\
\text { Produksi }\end{array}$ & $\begin{array}{c}\mathrm{kg} / \text { minggu } \\
\text { Omzet }\end{array}$ & $\begin{array}{c}\text { kg/minggu } \\
\text { Rp }\end{array}$ \\
\hline $\mathbf{4}$ & $\begin{array}{c}\text { Omp } \\
\text { Penghasilan }\end{array}$ & $1.440 .000,-$ & $3.975 .000,-$ \\
\hline $\mathbf{5}$ & Keawetan & 2 bulan & 5 bulan \\
\hline $\mathbf{6}$ & Luas & $\mathbf{2 ~ k o t a}$ & $\mathbf{3}$ kota (Mlg, \\
& pemasaran & (Mlg, Bali) & Menado) \\
\hline
\end{tabular}

Pada Tabel 1 menunjukkan adanya peningkatan efektivitas produksi dan omzet penghasilan. Selain itu nampak pula perluasan daerah pemasaran dari 2 kota menjadi 3 kota.

\section{ULASAN KARYA}

Pada kegiatan ini memiliki keunggulan dalam memberikan alat sangrai otomatis dan beberapa pelatihan manajemen yang dapat meningkatkan kesejaheraan keluarga. Saat ini persaingan usaha bumbu pecel semakin pesat sehingga dengan adanya bantuan alat dan pengetahuan manajemen maka dapat bersaing dengan baik dikalangan usaha bumbu pecel yang lain. Untuk lebih meningkatkan usahanya perlu adanya alat pencetak bumbu pecel secara otomatis dan berjalan semi kontinue. Diharapkan dengan adanya alat tambahan ini dapat mengurangi beban kerja mitra sehingga tidak perlu lagi memperkerjakan karyawan lagi jika permintaan meningkat. Selain itu akan mengurangi biaya ongkos untuk karyawan sehingga semakin efektif dan efisien dalam penggunaan. Hal inilah yang akan lebih memperkuat persaingan usaha bumbu pecel diluar sehingga memiliki nilai lebih dibandingkan dengan usaha bumbu pecel yang lain.

Dengan adanya alat baru atau teknologi baru memungkinkan memiliki nilai penting dan strategis untuk menembus pasar lebih dalam berkenaan dengan penguatan sektor riil pada masyarakat.

\section{DAMPAK DAN MANFAAT KEGIATAN}

Dampak dari adanya penambahan alat dan pengetahuan yang diberikan kepada mitra adalah usaha mitra semakin meningkat dengan meningkatnya kapasitas maka penghasilan semakin bertambah. Pengetahuan semakin bertambah dengan menguasai cara menghitung kelayakan usaha menggunakan analisa BEP sehingga dampaknya mitra bisa mengetahui untung rugi usaha.

Membuat laporan keuangan yang sederhana sehingga mitra semakin rapi dalam penyusun pembukuan keuangan dan mengetahui berapa laba bersih dan kotor serta mengetahui dengan persis berapa besar peningkatan usahanya tanpa harus bercampur aduk dengan laporan keuangan rumah tangga. Pengetahuan semakin bertambah dengan adanya teknik komunikasi pemasaran sehingga memperluas daya jual beli barang dagangan lebih banyak sehingga dampaknya dapat dilihat dari 2 kota menjadi 3 kota pelanggan. Manfaat dari kegiatan Program Kemitraan Masyarakat ini adalah secara keseluruhan dapat meningkatkan pendapatan keluarga dan kesejaheraan keluarga. 


\section{KESIMPULAN}

Penghasilan semakin meningkat 176\%. Kapasitas semakin bertambah 50\% untuk kedua mitra sehingga dapat memenuhi permintaan pasar. Beban pekerjaan semakin ringan dan lebih cepat sehingga tidak diperlukan tenaga kerja tambahan. Waktu proses lebih efektif 56\%. Pengetahuan semakin bertambah dengan adanya penyuluhan dan pelatihan ketrampilan penggunaan alat sangrai otomatis dan alat pengemas continue.

Pengetahuan semakin bertambah dengan adanya aplikasi analisa BEP dalam mengetahui untung rugi usaha. Pemahaman semakin meningkat dengan adanya ketrampilan membuat laporan keuangan sederhana dalam usaha bumbu pecel. Pengetahuan semakin bertambah dengan adanya teknik komunikasi pemasaran sehingga memperluas daya jual beli barang dagangan lebih banyak.

\section{PENGHARGAAN}

Ucapan terima kasih disampaikan kepada DRPM Kemenrintekdikti yang telah mendanai Program Kemitraan Masyarakat dan semua pihak yang telah mendukung jaalnnya kegiatan tersebut serta kesempatan yang diberikan oleh pihak Kampus Universitas Tribhuwana Tunggadewi Malang sehingga dapat berjalan dengan lancar.

\section{DAFTAR PUSTAKA}

[1] Uchyani R. Dkk, 2016, Pengembangan Pasar Produk Olahan Kacang melalui Perbaikan Kemasan, Asian Journal of Innovation and Entrepreneurship, Vol.01, o.01,Januari2016,Semarang.

[2] Agnis F.R ,dkk, 2015, Gambaran Jamur Aspergillus Flavus pada Bumbu Pecel; Instan dalam Kemasan tanpa Merek yang Dijual di Pasar Gedong Tataan Kabupaten Pesawaran, Jurnal Aalis Kesehatan, Vol.4 No.2, September 2015, Lampung

[3] Indrajaya Y.C., 2015, Perancangan desain Kemasan Sambal Pecel "Bumbu Ndeso Blitar", Surabaya. 